\title{
Empowerment of Palm Sugar Peasants at the Forest Edge of Bogani Nani Wartabone National Park, Indonesia: A Study of Problems, Local Potentials, and Priority Ideas Towards Empowered Community
}

\author{
Muhammad Obie ${ }^{1}$, Indra Dewi Sery Yusuf ${ }^{2}, \&$ Sumarni Sumai ${ }^{3}$ \\ ${ }^{1}$ Department of Sociology, Faculty of Ushuluddin and Dakwah, State Islamic University of Sultan Amai \\ Gorontalo, Indonesia \\ ${ }^{2}$ Department of Communication, Faculty of Ushuluddin and Dakwah, State Islamic University of Sultan Amai \\ Gorontalo, Indonesia \\ ${ }^{3}$ Department of Communication, Faculty of Ushuluddin and Dakwah, State Islamic University of Pare-Pare, \\ Indonesia \\ Correspondence: Muhammad Obie, Department of Sociology, State Islamic University of Sultan Amai Gorontalo, \\ Indonesia. Tel: 62-8-134-5790-642. E-mail: obiclimber@gmail.com
}

Received: February 2, 2019

Accepted: February 20, $2019 \quad$ Online Published: February 28, 2019

doi:10.5539/enrr.v9n1p77

URL: https://doi.org/10.5539/enrr.v9n1p77

\begin{abstract}
This study analyzed the roots of problem of palm sugar peasants at the forest edge of Bogani Nani Wartabone National Park; local potentials in producing palm sugar as a livelihood base; and their priority ideas to create empowered communities. Data collection was done through observation, in-depth interviews, Focused Group Discussion, and literature. The results showed that there were many problems faced by peasants in producing palm sugar, namely the forest where they took firewood was taken over by the national park; discourse on resettlement following the construction of a reservoir; damaged road infrastructure; did not have adequate means of producing palm sugar; uneven government assistance; and marketing of palm sugar through middlemen. In addition to the existing problems, it turns out that there were a number of local potentials that peasants had in developing palm sugar production, namely palm trees growed naturally; palm gardens owned by the peasants themselves; every peasant had sufficient knowledge how to produce palm sugar; palm sugar production was a tradition from generation to generation; solidarity ties were still very strong; the existence of village-owned enterprises; and the concern of the village government to palm sugar peasants. Palm sugar peasants had a number of priority ideas to create an empowered community, namely asking the government to revoke the status of the national park area that took over the forest where peasants take firewood; stopped or moved the reservoir construction plan; road infrastructure improvements; assistance with facilities and infrastructure for producing palm sugar; assistance allocated by the government to prioritize poorer people who had never received before; and standardization of palm sugar prices.
\end{abstract}

Keywords: Empowerment, Peasants, Palm Sugar, National Park, Bogani Nani Wartabone

\section{Introduction}

The reality shows that there are still many potential natural resources that have not been utilized as well as possible by local communities. Palm plants, for example, can be found in almost all parts of the archipelago, although not all regions use them to improve the local economy. Even in some regions, the existence of palm sugar plants become the problem root of social insecurity. For some areas in Sulawesi island, such as at the forest edge of Bogani Nani Wartabone National Park (BNWNP), palm trees are the source of high alcoholic liquor. By the local community, the flower arm of palm tree is processed to produce palm sap.

This community produces palm sap as the raw material for producing palm sugar. The palm sugar business is classified as a type of home industry because it can be done individually at homes of each peasant. Tapping is usually done by men, then the process of cooking to be sugar is done by the women at home. The production process of palm sugar at the peasant level is done with very simple equipment, such as bamboo as a container for 
palm sap, cauldron, stirrer, stove, firewood, palm filter, tapping machete, bat, palm sugar mold made of wood.

For the community at the forest edge of BNWNP, laborers in producing palm sugar come from family members. The tapper is carried out by the husband, while cooking it into palm sugar is done by the wife. The main source of livelihood for peasants come from palm sugar. This community is classified as a subsistence peasant who is only enough to fulfill daily needs. Many people's gardens are overgrown with natural palm trees. Therefore, the main work of peasants, especially men are tapping palm which is later cooked by their wifes into palm sugar. Producing palm sugar is a basic work of peasants that has been going on for a long time. This profession lasted for generations from their ancestors for centuries. However, the work which they are carrying out as palm sugar producers does not lift their fate from poverty and powerlessness. This condition inspired a sense of empathy from researchers to examined the roots of problem they face, the local potentials they have, and the priority ideas that emerge in a participatory manner to solve the problems they are experiencing, so that an empowered community is expected to be realized.

Empowerment is the process of developing, empowering, strengthening the bargaining position of the lower classes of society against suppressive forces in all sectors of life (Eko, 2002). Empowerment is an effort to expand the choice horizon for the community. This means that the community is empowered to see and choose something that is beneficial to them. Using this logic, it can be said that empowered communities are those who can choose and have an opportunity to make choices (Mahendrawati \& Syafei, 2001). Empowerment according to Friedman (1992) is the alternative development emphasizes political primacy through autonomy in decision-making to protect people's interests based on personal resources, directly through participation, democracy and social learning through direct observation.

Community empowerment is an economic development concept that summarizes social values. This concept reflects the new paradigm of development, which is people centered, participatory, empowering, and sustainable (Chambers, 1995). The main approach in the concept of empowerment that society is not the object of various development projects, but as the subject of its own development efforts. Based on this concept, community empowerment must follow the following approach (Sumodiningrat, 1999). First, the effort must be directed. This is popularly called partiality. This effort is aimed directly at those who need it, with programs designed to address the problem and according to their needs. Secondly, this program must be directly included or even implemented by the target community. Third, using a group approach, because individually the poor are difficult to solve the problems they face. This group approach is the most effective and the use of resources is also more efficient.

The empowerment program involves the local community as a subject to recognize the root of the problems they face, as well as resolve these problems by utilizing local potential in a participatory manner. Peasants who live at the forest edge of Bogani Nani Wartabone National Park utilize the potential of palm trees to produce palm sugar. In addition to consumption at the household level, palm sugar is also a raw material for various food industries such as the soy sauce industry, tauco, cookies products, and various traditional food products (Santoso, 1993). Sugar is one of the most important food needs for daily needs, both in the household or food and beverage industries, both large and small. Sugar becomes very important because sugar contains the calories needed for health and sugar is also used as the main sweetener used by many food and beverage industries (Sugiyanto, 2007).

Palm sugar produced by craftsmen as well as those obtained in the market generally in the form of solid sugar and its quality varies, in terms of durability, color, and content of impurities. The presence of color diversity and density in palm sugar products can be caused by a variety of things, such as low processing technology, variations in raw materials (palm conditions) and inconsistence processing (Santoso, 1993).

Maemonah's research (2015) concludes that the strategy that could be carried out to empower small palm sugar industries is a concentration strategy through horizontal integration. This means that the strategy applied is more defensive, which is to avoid losing sales and losing profits caused by threats. The Antomi and Balkis (2011) study concludes that palm sugar with agroforestry systems and palm sugar which are processed using coal fuel is feasible. So far, the results of research on palm sugar show that the production of palm sugar is very potential to be developed. The production of palm sugar can be either liquid or solid. What distinguishes this research from previous studies is the side of empowerment in utilizing the local potential of palm sap in community living on the edge of the forest. 


\section{Research Methods}

Data collection in this research used several techniques, namely: 1) observation; 2) in-depth interviews; 3) Focused Group Discussion (FGD); and 4) literature study. Arikunto (2010) explains that observation is a direct observation of an object that is in the ongoing environment, including various attention activities towards the study of objects using sensing. In line with that, Sudjana (2006) defines observation as a research method to measure individual actions and processes in an observed event.

Meanwhile, in-depth interviews are the processes of obtaining information for research purposes by way of question and answer face-to-face between interviewers and respondents or people interviewed, with or without using interview guidelines where interviewers and informants are involved in relatively long social life (Sutopo, 2006). Esterberg (2002) stated that interview is a meeting between two people to exchange information and ideas through question and answer so that meaning can be constructed in a particular topic.

Another technique used in collecting data was the FGD method. Irwanto (1998) explaines that FGD is a process of gathering information on a particular problem that is very specific through group discussions. Henning and Columbia (1990) state that FGD is an interview from a small group of people led by a moderator who subtly encourages participants to dare to speak openly and spontaneously about things that are considered important related to the topic of discussion being discussed. Carey (1994) describes the characteristics of the implementation of the FGD method, which is to use semi-structured interviews to an individual group with a moderator who leads discussions with informal settings and aims to collect data and information on topics of a particular issue.

The literature study method is a technique of collecting data by conducting study studies of books, literature, records, and reports that have to do with the problem being solved. This technique is used to obtain the basics and opinions in writing carried out by studying various literatures that relate to the problem under study (Nazir, 2013). To conduct a literature study, the library is an appropriate place to obtain materials and relevant information to be collected, read and studied, recorded and utilized.

Data analysis in this study was carried out through a qualitative approach. Qualitative research is research that intends to understand the phenomenon of what is experienced by the subject of research, for example behaviors, perceptions, motivations, actions, etc. holistically, and in a descriptive way in the form of words and language, in a specific context natural and by utilizing various natural methods (Moleong, 2007). Danial and Nanan (2009) suggest that a qualitative approach based on penomenologists demands a holistic approach, meaning holistic, placing a study in a multiple construction. Seeing an object in a natural context is not a partial.

Like the qualitative approach, the data collected was analyzed qualitatively and the results were presented in a descriptive analytical manner. Malo and Trisnaningtias (1996) state that descriptive research offerings are expected to answer in more detail about the social phenomena intended in a research problem concerned. Descriptive analysis method according to Nazir (2013) is intended to investigate in detail the activities and work of humans and the results of these studies can provide recommendations for future needs.

The data in this study were first sorted, categorized, and grouped according to analysis needs. Data sorting was done by completing and transforming raw data written in field notes so that it became a systematic report, completing information collected with other supporting sources. The second step was in the form of grouping data on the basis of the aspects studied, the level, and the type of information that could be collected. The data was then related to the subject matter being studied.

\section{Results and Discussion}

\subsection{The Problems of Palm Sugar Peasants at the Forest Edge of BNWNP}

There are a number of problems faced by palm sugar peasant at the forest edge of BNWNP. First, the forest where peasants take firewood and tap palm sugar taken over by BNWNP. Forests for palm sugar peasants are the main resource, both as a place to grow palm trees, as well as sources of firewood to cook palm sugar. Palm sugar that is cooked for about 6 hours, requires more firewood. Palm sugar peasants begin to have difficulty getting firewood when the forest where they take firewood is raised to a national park, as part of BNWNP.

"We have difficulty finding firewood to cook palm sugar. We used to take it in the forest, but now it's not allowed because it's guarded by national park officials. We have experienced this since a few years ago when our forests were taken over as part of the Bogani Nani Wartabone National Park" (Rauf, 2018) 


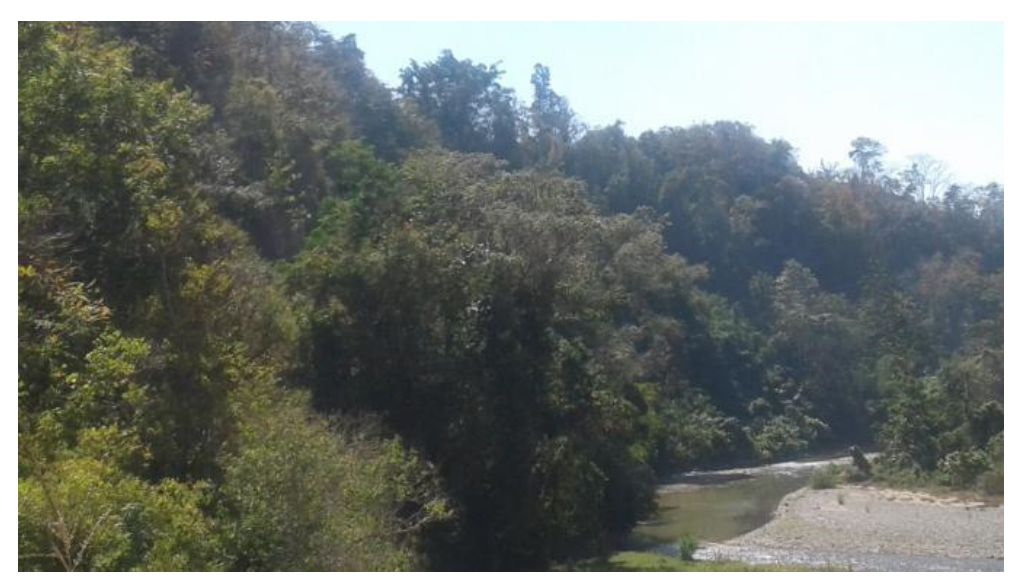

Figure 1. The forest taken over by BNWNP

The takeover of the forest is part of the 14,000 hectares of BNWNP in several buffer zones of the national park following the Decree of the Minister of Forestry of the Republic of Indonesia Number 324 / Menhut-II / 2010 dated 25 May 2010 which ratified changes in the allocation of 22,605 hectares of forest in Bone Bolango District, Gorontalo Regency, North Gorontalo Regency, and Boalemo Regency, Gorontalo Province. The 14,000 hectares that were converted was part of the BNWNP area.

"Forests in this area are included in the National Park section of Bogani Nani Wartabone for replacing the TNBNW forest area of 14,000 hectares which has been converted into a mining location for PT. Gorontalo Mineral Tbk" (anonimous, 2018)

According to Rahim's records (2017), exploitation activities by PT. Gorontalo Mineral in the ex-BNWNP forest area was carried out since 2012 with drilling activities, geotechnical investigations, geohydrology and Environmental Impact Assessment (EIA) studies. Prior to that, through the Decree of the Minister of Energy and Mineral Resources Number: 488.k/30/DJB/2010 dated November 1, 2010 concerning the extension of exploration licenses to PT. Gorontalo Mineral to conduct feasibility study activities. Meanwhile, the Decree of the Minister of Forestry of the Republic of Indonesia Number: SK 456/Menhut/2011 dated 5 August 2011 concerning the extension of licenses to use forest areas for gold and mineral exploration activities of followers in protected forest areas, limited production forests, production forests still gave authority to PT. Gorontalo Mineral to carry out road construction activities, build base camps, and determine exploitation coordinate points for 2 (two) months.

The policy of takeover of the forest areas into the BNWNP area has caused the loss of access to forest resources which is the source of raw materials for the production of palm sugar for local communities. Meanwhile, at the same time, the state actually gave the widest possible access to the corporation, PT. Gorontalo Mineral, to exploit forest areas. This finding was in line with the research by Obie et al. (2014) on the coast of Tomini Bay where the entry of PT WS's wood industry which was licensed by the state in the form of cultivation rights in the mountains of Popayato and utilizing the coast as a port area for loading and unloading of vessels belonging to PT WS has caused the loss of Bajo Tribe living on the coast of Tomini Bay. Referring to the concept of the bundle of power by Ribot and Peluso (2003), the state policy for taking over of the forest areas has weakened and even closed the access of palm sugar peasants. The closure of access to forest resources according to Forsyth (2003) is the cause of local communities experiencing poststructural pressures, namely the loss of access to forest resources that are the basis of their livelihoods.

The second problem is the discourse of resettlements following the government plan to build a reservoir. Palm sugar peasants who live at the forets edge of BNWNP experience mass worries as a result of the planned resettlement following the central government's policy that stipulates their settlement as the site of the construction of a giant 800 -hectare dam. The reservoir project that was started to be socialized by the Sulawesi River Regional Office II and the Gorontalo Provincial Government since 2017 has been rejected by residents because it has never been given the clear information about the construction of reservoirs in their area. Meanwhile other residents who work as palm sugar peasants feel sad when they have to be relocated because they will lose their livelihood base from producing palm sugar. 
"Since ancient times our ancestors have lived here with livelihoods of producing palm sugar. Every day we produce palm sugar, and the products are enough to fulfill our needs every day. If we are relocated from this village, we will automatically lose our livelihood from producing palm sugar" (Adam, 2018).

The development of the Bulango Ulu reservoir is one of the 245 projects designated as National Strategic Projects in Presidential Regulation No. 58 of 2017. The construction of this reservoir has the potential to affect around 1900 residents or around 700 Families who inhabit Mongiilo and Owata Villages at the forest edge of BNWNP. The planned construction of the dam caused the affected residents to no longer care about their environmental conditions, even they no longer repaired damage to their homes.

"Residents here had been apathetic, they didn't want to repair their damaged homes, let alone build new homes. They thought they wolud be relocated soon anyway. What's worse, many of them were lazy to produce palm sugar, even though it's their job since ancient times. They were pressured to think in a new location that it would be difficult to continue their profession as palm sugar producers" (Idrus, 2018)

Facing the plan to build the reservoir, residents formed a special team to fight, both through demonstrations, rejection of government explanations, citizen advocacy, etc. However, the government which has the security institutions, police and army, is too strong to be resisted by civil society. In the end, the people's protests led to a lack of clarity about the value of the land compensation promised by the government.

"The value of compensation for land and buildings promised by the government was confusing in the community. Some said compensation would be stored in envelopes without prior agreement with residents. In this case the value of compensation depends on government policy, but there was also information on the value of compensation depending on assets owned by residents including incentives as long as residents are in a new location" (Idrus, 2018).

Regarding this issue, it appears that the government ignores the principle of decentralization where development should be planned in a participatory manner. Residents even wonder the attitude of the government, which ignores development ideas that were very urgent through development planning meetings which had never been carried out by the government.

"We need road infrastructure repairs, so that access to the city can be smooth. We need the palm sugar production house. We need the access to marketing palm sugar made by peasants here. We need palm sugar production training to improve the quality of sugar production in this area, and others. We begged the government to stop the reservoir construction plan" (Adam, 2018).

Meanwhile, on the other hand, the Sulawesi River Regional Office II insisted that the planned construction of the Bulango Ulu reservoir was in accordance with the stages and there were no problems when socialization was held. The first stage was a feasibility study conducted in 2015 and received a warm welcome from the local community. The second phase of 2016 was carried out by geological review. The second stage also carried out detailed design as well as EIA activities.

The third problem is that road infrastructure is badly damaged. Roads that had been severely damaged became obstacles to people's access to the city center, as well as to the sub-district market. A steep rocky road with damaged conditions makes it difficult for people to sell palm sugar to the sub-district market. Roads in this area even passed small rivers without bridges.

The government didn't repair roads in this area for a long time, even though damaged road conditions have caused the selling price of palm sugar at the farm level to be very cheap. This low-cost sale caused the results received by palm sugar peasants were also small, while when they bought daily necessities, especially goods originating from the city, residents had to spend a lot of money because the price was very expensive. The poor rural infrastructure at the forest edge of the national park has been increasingly severe and alarming since the government planned the construction of reservoirs, where all physical project development was eliminated. This condition has increasingly marginalized residents living on the forest edge of the national park.

Another problem is that the peasants do not have a palm sugar sterilization base. The absence of a sterilization base is an obstacle for peasants to be able to produce quality palm sugar. This sterilization base is very useful for improving the quality of palm sugar made by peasants. Peasants have submitted the procurement of this sterilization base but it has never been ignored by the government. Peasants are forced to use makeshift traditional tools. Palm sugar peasants hope that this problem could be resolved by the local government so that the quality of palm sugar would be high quality. 


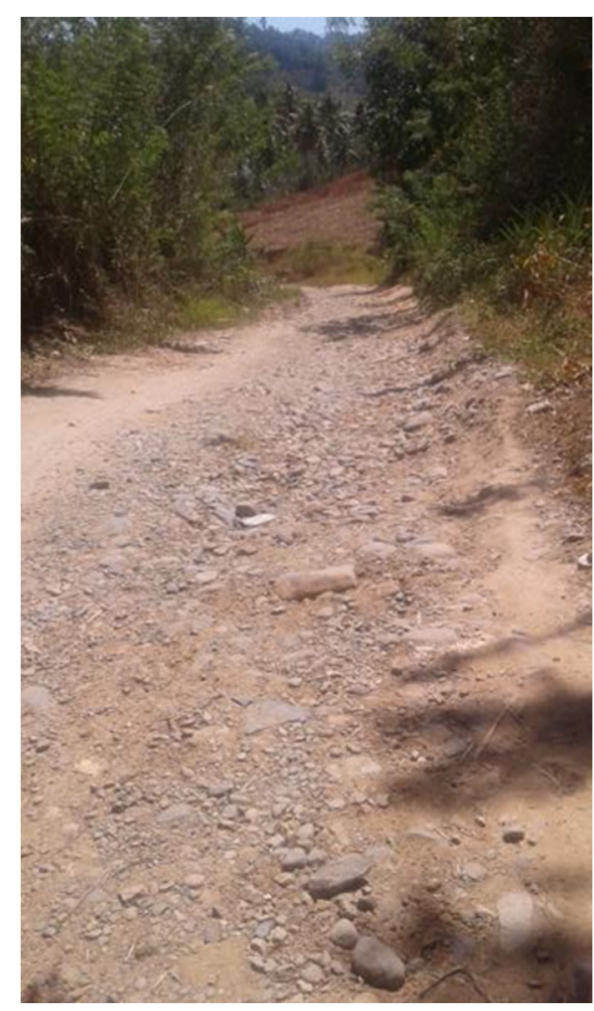

Figure 2. The rocky steep road on the forest edge of BNWNP

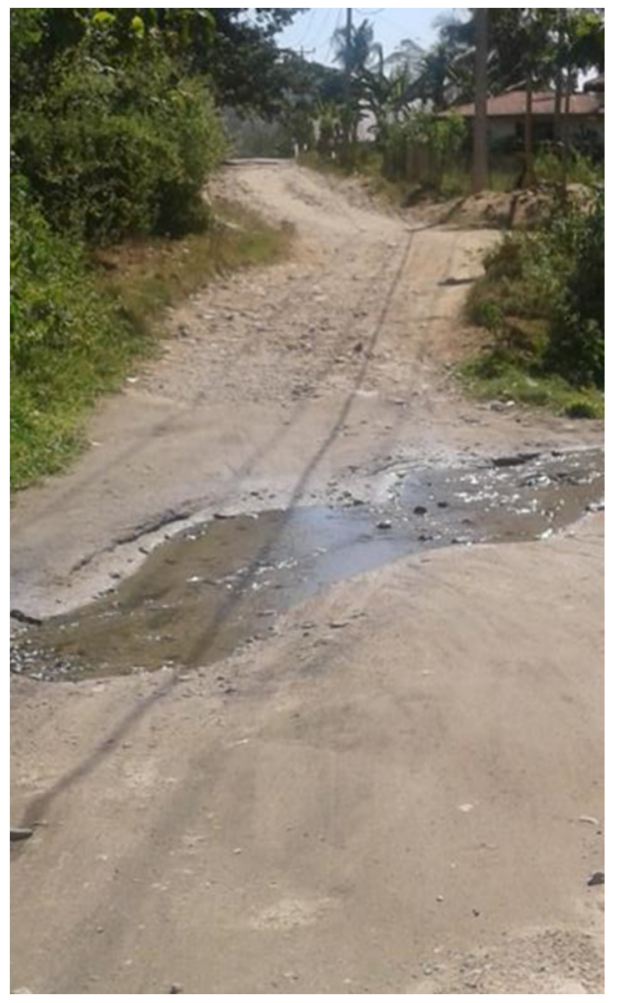

Figure 3. The river divides the highway at the forest edge of BNWNP

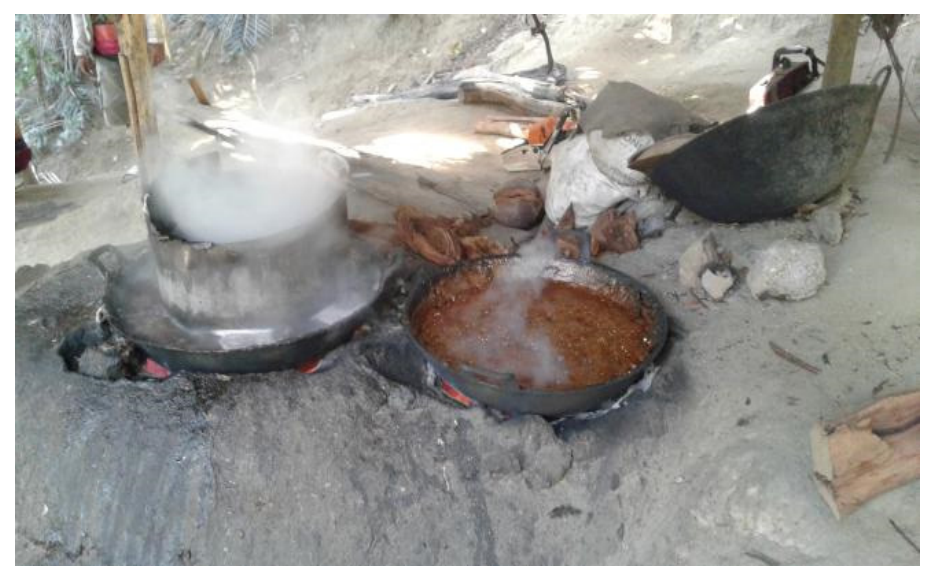

Figure 4. Cooking palm sugar traditionally

Uneven government assistance was also the problem faced by peasants. The regional government of Bone Bolango Regency, Gorontalo Province, once provided assistance with the production of palm sugar, in the form of a house for producing palm sugar and cauldron to cook palm sugar. The problem was that not all palm sugar peasants get the assistance. As a result, mutual suspicion in the peasant community cannot be avoided. Residents who did not receive assistance accused the local government of being so favoritistic that only certain groups received assistance. In addition, disputes among fellow citizens who got assistance with those who didn't get assistance also occur, in the form of mutual suspicion, self-determination, and others.

Finally, the problem of marketing palm sugar is through middlemen. Even in certain cases, peasants took money earlier from middlemen then got paid using palm sugar at very cheap prices. Peasants sold palm sugar to middlemen once a week, every Wednesday, then by middlemen sold it back to agents at the sub-district market. 


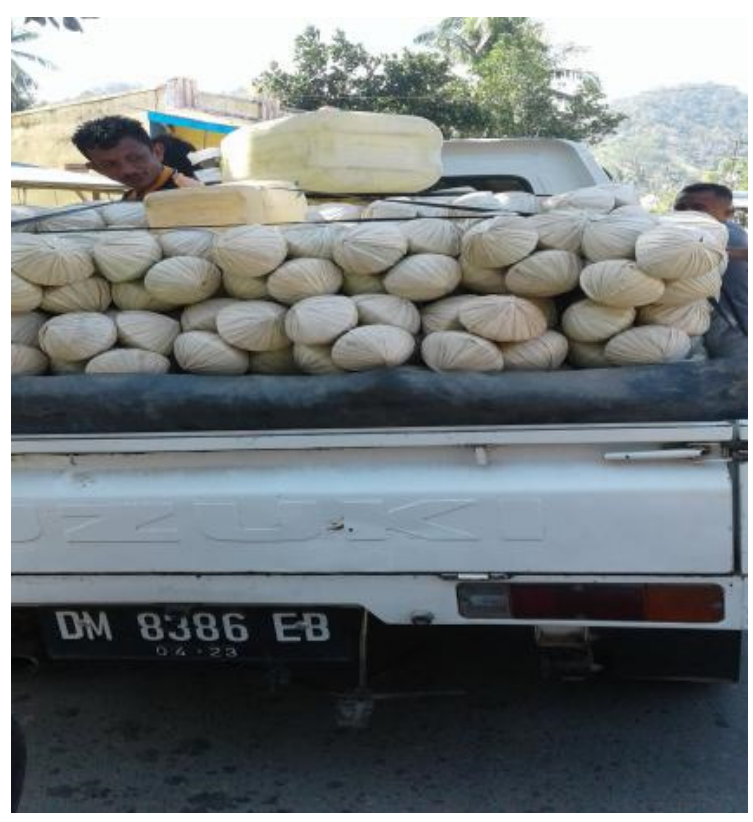

Figure 5. Middleman brought his merchandise, palm sugar, to the sub-district market

The sale of palm sugar through middlemen was actually very strangling the neck of palm sugar peasants. The price of 1 bunch of palm sugar is 20 seeds purchased by the middlemen for Rp. 80,000 to Rp. 100,000, while the middlemen sold it back to the sub-district market for Rp. 210,000,000 binders. However, peasants did not have choice to sell their artificial palm sugar to others because only the middlemen are the only buyers of palm sugar owned by farmers. In such conditions, the fate of palm sugar peasants does not change, remains in a state of poverty and helplessness.

\subsection{The Local Potentials of Palm Sugar Peasants}

Palm sugar peasants have a number of local potentials that can be utilized to reach empowered communities. First, palm trees grow naturally. Palm trees as the main source of palm sugar are available in large quantities, both in the forest areas, and outside of the national park. Palm trees grow naturally in the peasants' garden without having to be planted or special cultivation. Every peasant has his own palm trees in a large amount.

"Every palm sugar peasant here has a lot of palm trees. The palm trees grow itself in the garden without having to plant it. We have never planted palm trees here, but there are so many palm trees available for us to treat them into palm sap and then we cook them into palm sugar" (Gani, 2018).

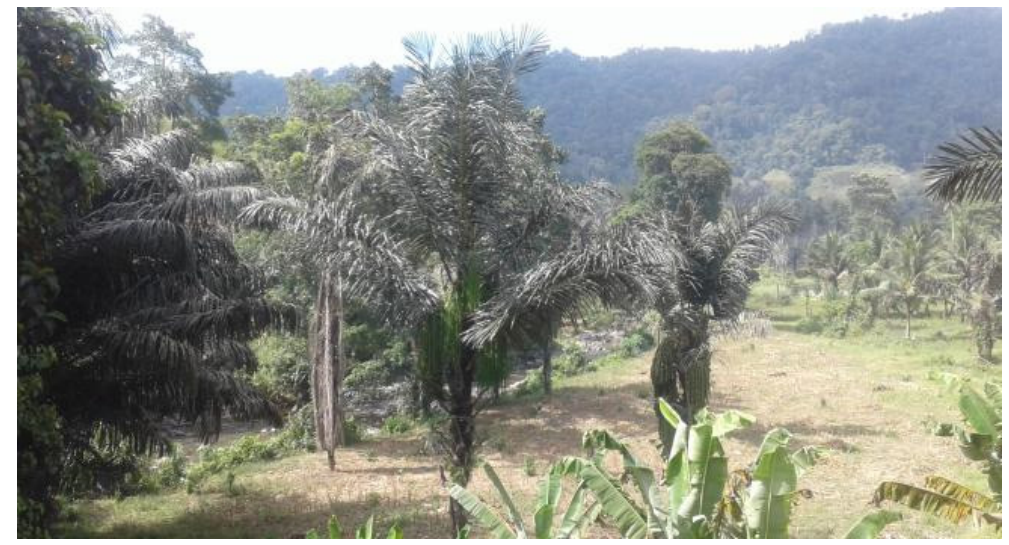

Figure 6. Palm trees grow naturally in the peasants' gardens 
The second local potential is that every peasant has his own large palm garden. Palm sugar peasants produce palm sugar from their own gardens. This is a potential since the peasants no longer need to spend money to buy palm sugar as raw material for cooking into palm sugar.

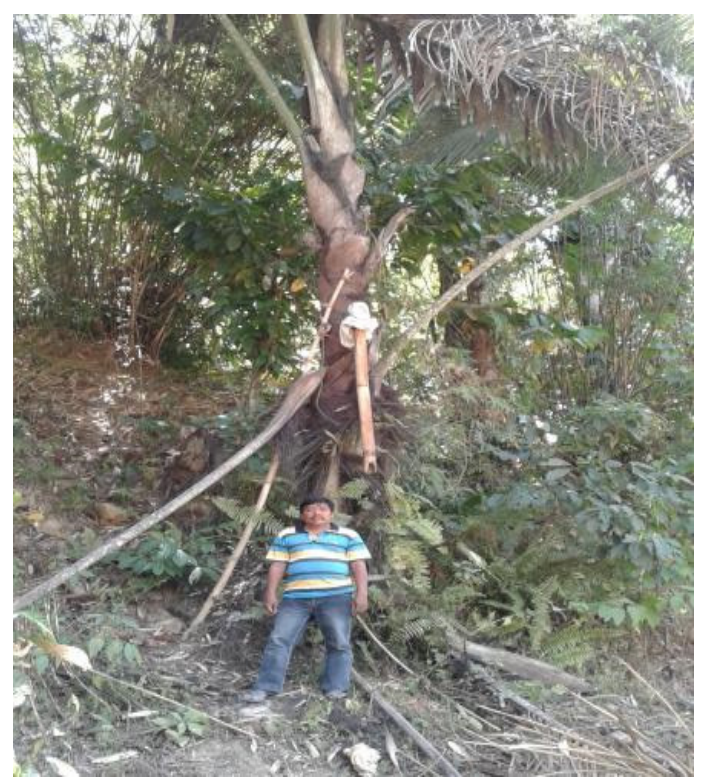

Figure 7. A palm sugar peasant, Mr. Adam, in his own garden

The third local potential is that every peasant has sufficient knowledge how to produce palm sugar. The basic knowledge of palm sugar peasant was inherited directly from their parents who were also palm sugar peasants. The process of inheriting this knowledge took place naturally, where since a child he watched his or her parents produced palm sugar. Just by watching their parent habit in producing palm sugar, the new generations are able to continue the work. This traditional knowledge is collaborated with modern knowledge through training.

Everyone at the forest edge of national park knows how to produce palm sugar. On average they watch their parents produce palm sugar. Even so, there are some craftsmen who have participated in training in the production of palm sugar, which is held both by the local government, as well as by the village government through village funds budgeting.

Production of palm sugar is a tradition from generation to generation. For residents who live at the forest edge of national park, producing palm sugar is not just a livelihood, but more than that is a tradition inherited from generation to generation from their ancestors.

"Our ancestors produced palm sugar since centuries ago. Producing palm sugar is our tradition here. Lots of offers as we switch to other jobs, but we don't want to. There were also offers to grow corn, which yielded greater yields each time, but we loved our ancestors' heritage" (Tuluti, 2018).

Producing palm sugar for residents at the forest edge of BNWNP is a pride for participating in maintaining the traditions of their ancestors. Therefore, every offer to switch to a new profession, such as farming corn, they do not accept. Although there are indeed some residents who participated in planting corn, they did not abandon the tradition of their ancestors producing palm sugar.

The existence of a strong bond of solidarity is also a local potential. The strong (mechanical) bond of solidarity is the social capital of the palm sugar peasant community at the forest edge of national park that is still preserved. Compared to the tenuous (organic) solidarity of the peasant life, in the countryside they still maintain collective actions in their daily activities. This fact corroborates the views of French Sociologists, Durkheim (1985 - 1917) on the division of society, namely mechanical solidarity and organic solidarity. With its mechanical solidarity, the rural community feels the same fate as one another, resolves every problem together, and is subject to collective norms.

Mechanical solidarity possessed by the palm sugar peasant community is a social potential and the reason why this tradition is timeless has passed. In the process of producing palm sugar, there is social interaction among 
fellow citizens, discussing each other about the sap trees they have, the palm water that is picked up on the palm tree by the husband morning and evening, the results of the palm sugar they produce, up to the sale of palm sugar done once a week before the market day to the nearest middleman.

The busyness they have in producing palm sugar does not prevent them from being active in community meetings in the local village office. If their busy time produces palm sugar is in the morning and evening, then the meeting of residents in the village office is arranged in the afternoon, so that residents who produce the palm sugar can take the time to attend the meeting on that day.

"Residents here if there is a meeting in their village office will definitely come. Their busyness in producing palm sugar in the morning and evening did not prevent them for attending invitations from the village government. They felt guilty if they did not attend the invitation because they realized it was for the mutual benefit of the villagers" (Podungge, 2018).

The palm sugar peasant community shows collective behavior up to meetings held by the village government. This strength is a potential for social security, so that the community of palm sugar peasants can solve every problem they face collectively. Other local potential is the Village-Owned Enterprises (BUMDes). BUMDes is village businesses formed or established by village governments whose capital management is carried out by the village government and the community. The establishment of BUMDes is based on Law No. 32 of 2004 concerning Regional Government and Government Regulation No. 72 of 2005 concerning villages. BUMDes is formed along with the implementation of the Village Fund Program in each village. The presence of BUMDes in the middle of the palm sugar peasant community is actually a great potential that can be utilized to overcome the problems they face so far. BUMDes can function to stabilize the price of palm sugar which has been regulated by middlemen for years so that palm sugar peasants always sell their palm sugar products below the price. The hope of peasants with the presence of BUMDes is that palm sugar peasants can sell their products through BUMDes at a stable price, not to be disguised as practiced by middlemen so far.

The village government cares for palm sugar peasants is as well as the potential to create this empowered community. The concern of the village government to continue for developing palm sugar production at the forest edge of BNWNP is the potential for the continuation of the tradition of producing palm sugar. The form of concern of the village government is shown by always coordinating with the local government to allocate special assistance for palm sugar peasants. In addition, the village government also continues to motivate palm sugar peasants to improve the quality of their products so that they continue to gain consumer trust.

\subsection{The Process of Producing Palm Sugar}

The process of producing palm sugar uses family labor. The family labor involved in this process is husband and wife. The husband first looks for the female flower of palm tree that is ready to be processed. After finding and making sure the flower is ready to be processed, the husband starts cleaning and goes through a process of several weeks until the female flower is ready to be cut and the sap water can be produced. When the sap is produced, usually husband and wife together two times a day go to the garden to take palm sugar. The husband climbes the tree to pick up the bamboo which is filled with nira water, while the wife waits under the tree to pick up the bamboo.

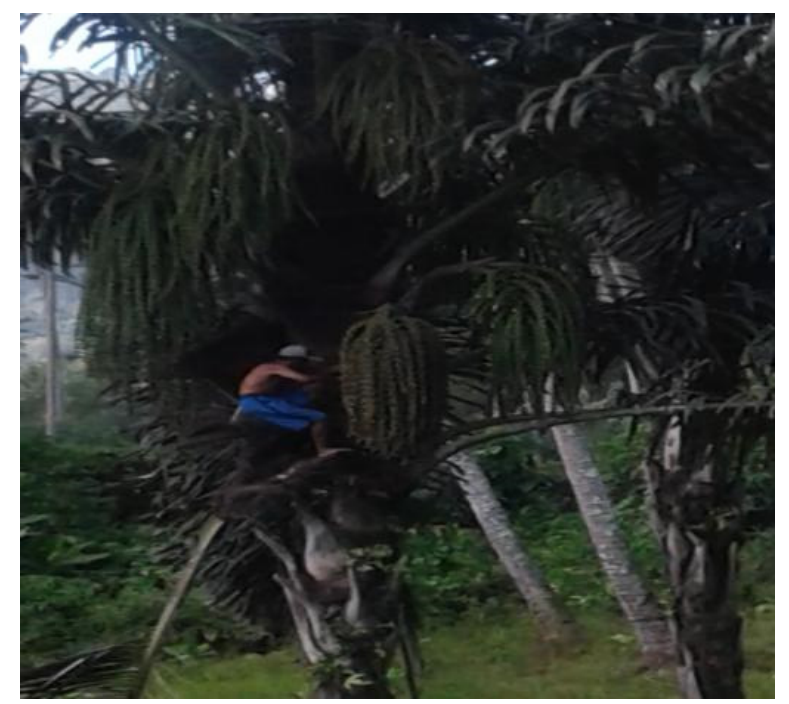

Figure 8. Palm sugar peasant was cleaning the flower arm of the palm tree 
"Tapping palm sugar is done twice a day, morning around 6 or 7 a.m. and afternoon at 4 or 5 p.m. My husband is tapping, while I just wait under the tree. After my husband reached out to the bamboo containing palm sugar, the bamboo was lowered under the tree using a rope and I received it" (Lihawa, 2018)

The mixture of palm sap to produce good quality is the roots of Boyuhu wood (local wood). This Boyuhu wood roots is mixed into palm sugar when accommodates palm sap in bamboo. After arriving at home palm sugar is cooked for approximately 6 hours to produce palm sugar. The freshly cooked palm sugar is cooled a few hours before it is wrapped in a kind of sago palm leaf and ready to be marketed.

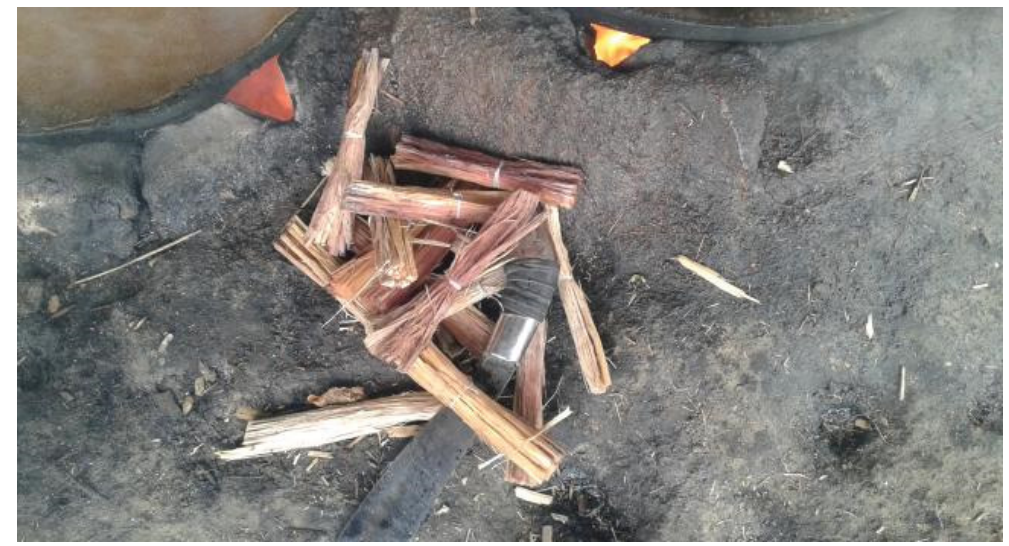

Figure 9. Boyuhu wood roots, a mixture of palm sap in the bamboo

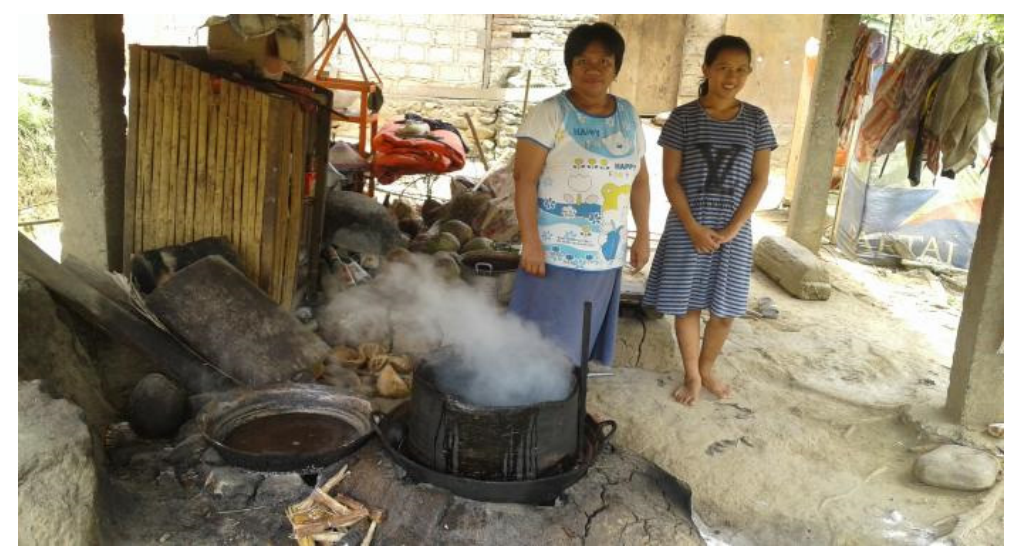

Figure 10. Mrs. Lihawa was cooking palm sugar, accompanied by her daughter-in-law

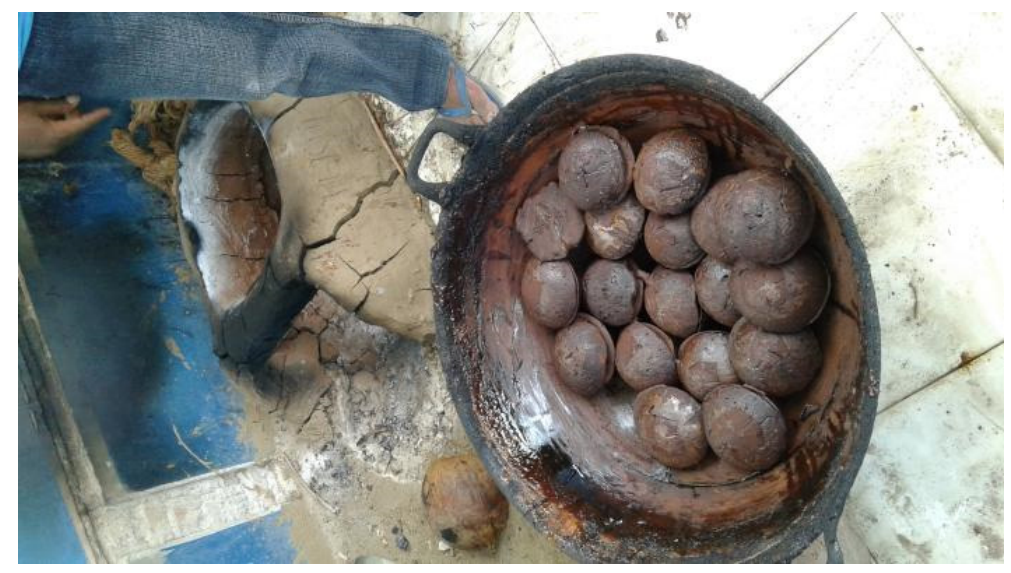

Figure 11. The freshly cooked palm sugar was cooled a few hours before it was wrapped in a kind of sago palm leaf 


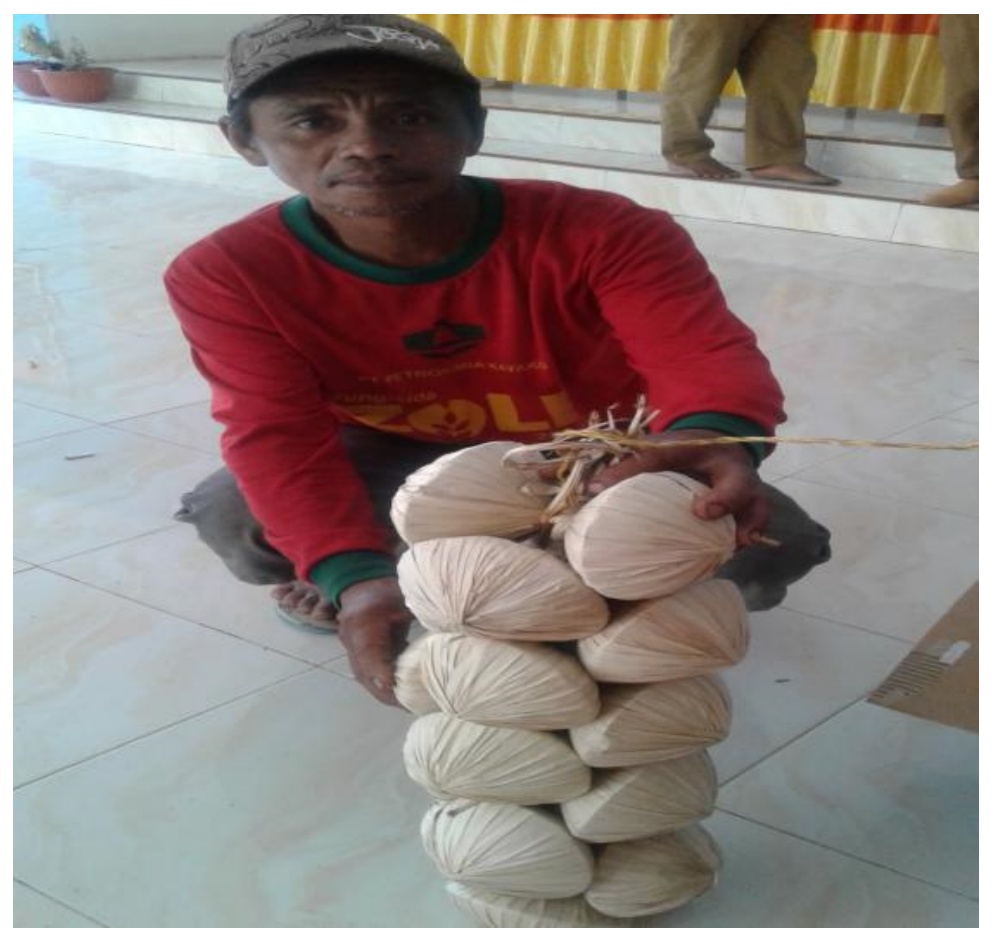

Figure 12. Mr. Usman showed off his homemade palm sugar which was ready to be marketed

\subsection{The Priority Ideas of Palm Sugar Peasants to Reach an Empowered Community}

The main target of community empowerment programs is the achievement of independent and empowered communities. Independence and empowerment can be realized intrinsically when the community is able to overcome the problems that they face by utilizing the local resources they have. The priority ideas of palm sugar peasants to create an empowered community, namely: i) revoke the status of BNWNP area that takeover the forest where residents take firewood; ii) Stop the reservoir construction plan; iii) road repairs; iv) assistance to be prioritized for poorer citizens; v) assistance with facilities and infrastructures for producing palm sugar; and iv) standardization of palm sugar prices

Revocation of BNWNP area ststus that has takeover the forest in their area is very urgent to be carried out by the government that is authorized because its existence has injured the justice of the community. The closure of access to forest areas which previously the community was free to take firewood to cook palm sugar showed unilateral arbitrariness carried out by the authorities to small communities. Even more painful after the community learned that it turned out that the access closure was carried out as a form of BNWNP forest swap which had been converted into a mining area of the corporation of PT. Gorontalo Mineral Tbk.

Peasants also spontaneously and together proposed the idea that the planned construction of the giant Bulango Ulu reservoir would not be resumed or had to be moved elsewhere. Peasants put forward this idea because they did not want to move from their current settlements which they had occupied for generations from their ancestors. Peasants also reason that moving residents from their current settlements is the same as moving fish from ponds to land. Fish will surely die because it comes out of its true place. Moving farmers from the forest edge of BNWNP that has fostered a socio-economic based on palm sugar to a new place will make it difficult for residents to adapt towards their environment. Moreover, citizens will lose their culture and tradition of producing palm sugar as the basis of their livelihood.

Residents suggested that the government pay attention to road improvements in their area. Although this idea has often been carried out, especially through development consultations meeting (musrembang) at the village level up to the district and provincial meetings, the government has never paid attention to their idea. Residents argue that road improvement is the most priority thing that must be done first since it is an opening access that will facilitate the realization of other development ideas.

"With this damaged road condition, everything we buy becomes expensive. Conversely, if we sell garden products, everything will be cheap. Therefore, we propose that the government want to listen to these complaints and improve our roads" (Ibrahim, 2018) 
According to residents, there is no point in all programs allocated by the government without being accompanied by road repairs. Road improvements cannot be negotiated anymore because this has been going on for a long time without any government attention. After the road infrastructure is repaired, then the farmers expect the help of facilities and infrastructure for producing palm sugar. The facilities and infrastructure needed by farmers in producing palm sugar is the house for producing palm sugar itself, cauldron and pans for cooking, and palm sugar sterilization bases. In several villages there has been assistance in the construction of houses for palm sugar The same goes for the assistance of cauldron and pan for cooking, but the assistance is not evenly distributed to all villages. While the base for sterilizing palm sugar to produce high quality palm sugar has never existed. Residents hope that villages that have never received assistance in the construction of houses for producing palm sugar, also cauldron and pan for cooking as much as possible can get the help. While the base for sterilization of palm sugar is the need of all palm sugar farmers so that their palm sugar production is of high quality.

So far, palm sugar peasants have used their huts to produce palm sugar. Residents hope to get help of building houses for palm sugar as well as assistance ever given to other palm sugar peasants. The current conditions when the rainy season arrives, peasants have difficulty to produce palm sugar because the huts they use often leak so that it affects the flame in cooking palm sugar.

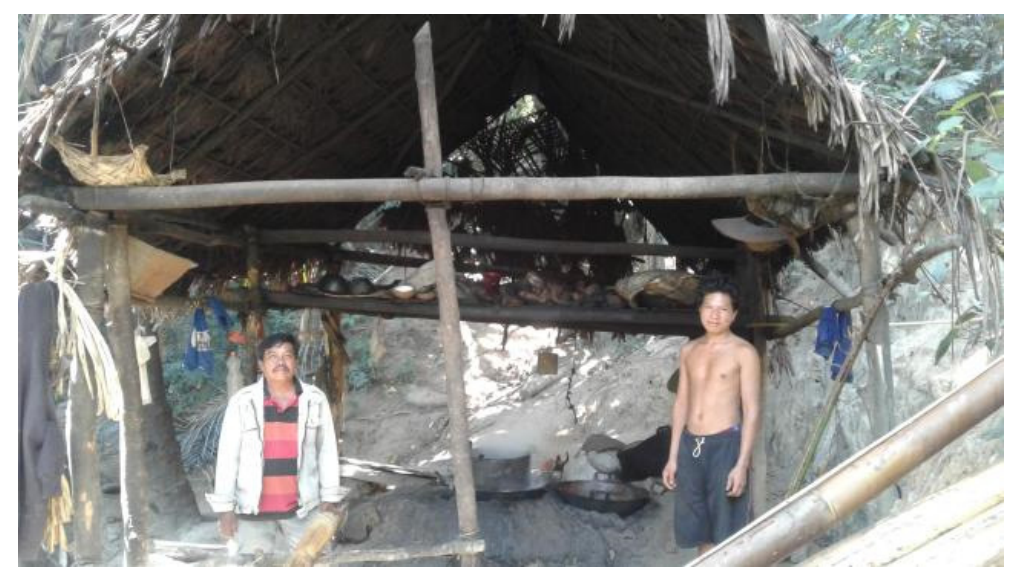

Figure 13. The hut where palm sugar is produced

Residents suggested that the assistance of facilities and infrastructure for producing palm sugar be prioritized by the poorer. In addition, those who have received assistance are temporarily not given since there are still many other residents who have not received assistance.

"Our village has never received the assistance of facilities and infrastructure for producing palm sugar. Villages there have often received assistance, even recently they have received assistance of building houses for palm sugar. Even though they have often received assistance, while we have not been here at all" (Ishak, 2018).

The priority scale of beneficiaries is very important to prioritize poorer people. Citizens know each other so that they know better who is more feasible and should be prioritized to get help. The ways of nepotism by prioritizing those who are closer to the authorities, citizens hope to stop it. Because according to residents, unfair practices such as these are the seeds of division in the community.

The last idea proposed by palm sugar peasants is the standardization of the price of palm sugar. Price standardization at the level of palm sugar peasants is by presenting buyers outside the middlemen who have existed so far. Palm sugar peasants fully expect the BUMDes to be an alternative to accommodate the peasants' palm sugar and sell it back to consumers. Peasants want the government to set the lowest selling price of palm sugar at the collecting level. With the standard pricing, the price game will not happen again. The existing practices have been very detrimental to palm sugar peasants. Prices can go up and down at any time depending on the middlemen's wishes so peasants sometimes have to bear the loss. The stable price of palm sugar is a step forward towards the independence and empowerment of the palm sugar farming community at the fprest edge of BNWNP.

\section{Conclusion}

Palm sugar peasants who live at the forest edge of BNWNP produce palm sugar have been going on for a long time which is inherited from generation to generation from their ancestors. However, their profession as palm 
sugar peasants is not able to lift their destiny from poverty and powerlessness. This was due to the many problems they faced, namely the forest where they took firewood for cooking palm suger takenover by the BNWNP; discourse on resettlement following the construction of a reservoir; damaged roads; do not have a palm sugar sterilization base; uneven government assistance; and marketing of palm sugar through middlemen.

The local potentials owned by peasants are palm trees grow naturally; palm trees are owned by the peasants themselves; every peasant has sufficient knowledge how to produce palm sugar; palm sugar production is a tradition from generation to generation; solidarity ties are still very strong; the existence of Village-Owned Enterprises (BUMDes); and the concern of the village government to palm sugar peasants. To realize an empowered palm sugar peasant community, there are a number of priority ideas desired by the peasants, namely the government is uprooted to revoke the status of the BNWNP area which takes over the forest where peasants take firewood; stop or move the reservoir construction plan; road infrastructure repair; assistance with facilities and infrastructure for producing palm sugar; assistance allocated by the government to prioritize poorer people who have never received assistance; and standardization of prices of palm sugar.

\section{Acknowledgements}

This research was carried out with financial support from the State Colledge Operational Assistance (BOPTN), State Islamic University of Sultan Amai Gorontalo, Indonesia, in 2018. Therefore, through this opportunity we express our deepest gratitude to the Rector of the State Islamic University of Sultan Amai Gorontalo, Indonesia, along with its staff. Our deepest gratitude is also conveyed to all village heads and their communities in the Bulango Ulu District, Bone Bolango Regency, Gorontalo Province, which has participated during the data collection of this research.

\section{Conflict of interests}

The authors declare that there is no conflict of interests regarding the publication of this paper.

\section{References}

Adam, A. B. (2018). (Personal Communication) September

Anonimous. (2018). (Personal Communication) September

Antomi, R., \& Balkis, S. (2011). Aspek Finansial Usaha Gula Aren dengan Sistem Agroforestri di Kecamatan Samboja Kabupaten Kutai Kartanegara. Jurnal Kehutanan Tropika Humida, 4(2), 161-172.

Arikunto, S. (2010). Prosedur Penelitian Suatu Pendekatan Praktik. Jakarta: Rineka Cipta.

Carey. (1994). The Group Effect in Focus Groups: Planning, Implementing, and Interpreting Focus Group in Research. In J. M. More (Ed.), Critical Issues in Qualitative Research Methods (pp. 225-241). Sage: Thosand Oaks.

Chambers, R. (1995). Poverty and Livelihood: Whose Reality Counts. Discussion, 347. Brighton: Institute of Development Studies.

Danial, E., \& Nanan, W. (2009). Metode Penulisan Karya Ilmiah. Bandung: Laboratorium Pendidikan Kewarganegaraan.

Eko, S. (2002). Pemberdayaan Masyarakat Desa, Materi Diklat Pemberdayaan Masyarakat Desa, yang diselenggarakan Badan Diklat Provinsi Kaltim, Samarinda.

Esterberg, K. G. (2002). Qualitatif Methods in Social Research. New York: McGraw Hill.

Forsyth, T. (2003). Critical Political Ecology: The Politics of Environmental Science. Roudge: London.

Friedman, J. (1992). Empowerment the Politics of Alternative Development. Cambridge, USA: Blackwell Publishers.

Gani, S. (2018). (Personal Communication) October

Henning, F., \& Columbia, R. (1990). Penyelenggaraan dan Penafsiran Hasil-Hasil Diskusi Grup Fokus. Majalah Kesehatan Masyarakat Departemen Kesehatan RI, 4, 35-39.

Ibrahim, S. (2018). (Personal Communication) September.

Idrus, Y. (2018). (Personal Communication) September.

Irwanto. (1998). Focused Group Discussion (FGD) Sebuah Pengantar Praktis. Jakarta: Pusat Kajian Pembangunan Masyarakat Universitas Katolik Indonesia Atma Jaya.

Ishak, H. (2018). (Personal Communication) October. 
Lihawa, I. (2018). (Personal Communication) September.

Maemonah, S. (2015). Strategi Pengembangan Industri Kecil Gula Aren di Kecamatan Limbangan Kabupaten Kendal. Semarang: Skripsi Fakultas Ekonomi UNNES.

Mahendrawati, N., \& Syafei, A. A. (2001). Pengembangan Masyarakat Islam. Bandung: Remaja Rosdakarya.

Malo, M., \& Trisnaningtias, S. (1996). Metode Penelitian Masyarakat. Universitas Indonesia: Pusat Antar Universitas Ilmu-Ilmu Sosial.

Moleong, L. J. (2007). Metodologi Penelitian Kualitatif(Edisi Revisi). Bandung: Remaja Rosdakarya.

Nazir, M. (2013). Metode Penelitian. Bogor: Ghalia Indonesia.

Obie, M., Soetarto, E., Sumarti, T., \& Saharuddin. (2014). Konflik Etnis di Pesisir Teluk Tomin: Tinjauan Sosio-Ekologi Politik. Al-Tahrir, 14(2), 321-342

Podungge, N. (2018) (Personal Communication) October.

Rahim, S. (2017). Konflik Pemanfaatan Ruang Akibat Penambangan Emas Tanpa Ijin (PETI) di Kawasan Hutan Produksi Terbatas. Jurnal GeoEco, 3(1), 17-25.

Rauf, I. (2018). (Personal Communication) September.

Ribot, J. C., \& Peluso, N. L. (2003). A Theory of Access. Rural Sociology, 68(2), 153-181.

Santoso, B. (1993). Pembuatan Gula Kelapa. Yogyakarta: Kanisius

Sudjana. (2006). Metode Statistik. Jakarta: Rineka Cipta.

Sugiyanto, C. (2007). Permintaan Gula di Indonesia. Jurnal Ekonomi Pembangunan, 8. Yogyakarta: Fakultas Ekonomi Uiversitas Gadjah Mada.

Sumodiningrat, G. (1999). Pemberdayaan Masyarakat dan Jaring Pengaman Sosial. Jakarta: Gramedia Pustaka Utama.

Sutopo, H. B. (2002). Metodologi Penelitian Kualitatif Dasar Teori dan Terapannya dalam Penelitian. Surakarta: UNS Press.

Tuluti, A. (2018). (Personal Communication) October.

\section{Copyrights}

Copyright for this article is retained by the author(s), with first publication rights granted to the journal.

This is an open-access article distributed under the terms and conditions of the Creative Commons Attribution license (http://creativecommons.org/licenses/by/4.0/). 